\title{
Effect of Motivation on Lecturer Performance at the Institute of Social and Political Sciences (IISIP), Yapis Biak
}

\author{
Sri Handayani \\ Institut Ilmu Sosial dan Ilmu Politik (IISIP) Yapis Biak \\ Email: sri.handayani@gmail.com
}

(Received: February 20-2019; revised: March 5-2019; published: May 31-2019)

\begin{abstract}
This study aims to analyze the effect of motivation on lecturer performance at the Institute of Social and Political Sciences (IISIP), Yapis Biak. Data collection is done by distributing questionnaires and conducting interviews involving all permanent lecturers who are active in the Yapis Biak Institute of Social and Political Sciences. The population in this study were 43 people. The data collection method used is a questionnaire. The research approach used is a qualitative approach and the data testing techniques used in this study are multiple linear regression analysis to prove the research hypothesis. The results of the study based on statistical tests, the results of multiple linear regression showed that motivation influenced the performance of lecturers at the Yapis Biak Institute of Social and Political Sciences with a regression coefficient of 0.808 .
\end{abstract}

Keywords: Motivation; lecturer performance; Organization

\section{INTRODUCTION}

An organization is formed to achieve certain goals (Andersson, Cäker, Tengblad, \& Wickelgren, 2019; Chu, Fu, \& Liu, 2019; Khunsoonthornkit \& Panjakajornsak, 2018) (Jamaluddin, Salam, Yunus, \& Akib, 2017; Salam \& Rosdiana, 2016). However, achieving goals requires good management and effective and efficient use of organizational resources. One of the most important organizational resources whose role in achieving organizational goals is human resources. The quality of human resources can be seen from the way and the results of their work are called performance. Performance is the result of work that has a strong relationship with the organization's strategic goals, customer satisfaction and economic contribution (Bruhn, Schnebelen, \& Schäfer, 2014; Ozer \& Gultekin, 2015; Wahab, Hassan, Shahid, \& Maon, 2016). Organizational goals can be achieved if the performance of human resources in the organization has been good. Factors that determine the level of work (work performance) of an employee, including the performance assessment (S. Saggaf, Salam, Kahar, \& Akib, 2014; Salam, Rosdiana, Suarlin, \& Akib, 2014; Stollberger, Las Heras, Rofcanin, \& Bosch, 2019).

The Republic of Indonesia Law Number 14 of 2005 concerning Teachers and Lecturers Article 1 paragraph (2) defines that lecturers are professional educators and scientists with the main task of transforming, developing and disseminating science, technology and art through education, research and community service. Lecturer performance is measured based on the lecturer workload includes the main activities, namely planning learning, carrying out the 


\author{
30| Jurnal Ilmiah Ilmu Administrasi Publik: Jurnal Pemikiran dan Penelitian Administrasi Publik \\ Volume 9 Number 1, January - June 2019. Page 29-36
}

learning process, evaluating learning, guiding and training, conducting research and community service and carrying out additional tasks.

Based on preliminary observations made by the lecturers' performance at the Yapis Biak Institute of Social Sciences and Political Sciences, it is still not optimal. This can be seen from the academic data which shows that only $75 \%$ of the lecturers prepared the Teaching Reference Unit at the beginning of the lecture, as well as the lecturers who carried out research and community service were only $12.3 \%$.

According to McClelland (1987) the emergence of motivation to do an act comes from the interaction between, otif with the factors - the situation situation. Motivation is one of the factors that will influence the performance improvement shown by human resources in an organization. Motivation is a willingness to try optimally in achieving organizational goals that are influenced by the ability of the business to satisfy some individual needs (Acar, 2018; Niswaty, Rusbiati, Jamaluddin, \& Salam, 2017; M. S. Saggaf, Nasriyah, Salam, \& Wirawan, 2018; Syam, Akib, Yunus, \& Hasbiah, 2018). The motivation given by the organization, human resources are increasingly motivated to continue to improve performance and do the best for the organization (Idzhar, 2016; Ningsi, Alhabsji, \& Utami, 2016; Sanjaya \& Baharuddin, 2014).

\title{
METHOD
}

This study uses an explanatory approach with an associative model, namely research that aims to determine the relationship of two or more variables. The method used in this study is quantitative with associative / relationship methods (Creswell \& Creswell, 2017). The scope of the research there are many factors that influence the performance of lecturers, in this study limited to motivational variables. The research was conducted at the Yapis Biak Institute of Social and Political Sciences. The types and sources of data in this study consist of quantitative data and qualitative data. Quantitative data in the form of numbers, variable numbers, which are obtained through secondary data in the form of tables, graphs and several other references relevant to this study. Qualitative data in the form of data in the form of words, statement sentences obtained through interviews, document analysis and observation. Data sources consist of Primary data and secondary data, primary data obtained from the results of questionnaires distributed to lecturers teaching at the Yapis Biak Institute of Social and Political Sciences. While secondary data is obtained by taking table data, academic reports stored in academic bureaus. The population in this study were 43 permanent lecturers of the foundation and lecturers at the Institute of Social and Political Sciences, Yapis Biak. Data collection techniques in this study include questionnaires, using a Likert scale assessment, interviews with lecturers at the Yapis Biak Institute of Social and Political Sciences, observation, and literature. Data Analysis Techniques in accordance with the above mentioned that this research is quantitative research with a relationship method, the data analysis technique used is Linear Regression with the equation $Y=a+b 1 X 1$. Product Moment Correlation Analysis and hypothesis testing with a test level of $5 \%$. 


\section{RESULT AND DISCUSSION}

Based on the results of the research carried out several tests to see whether motivation affects the performance of lecturers at the Yapis Biak Institute of Social and Political Sciences. Hypothesis testing is conducted to determine whether there is an influence of independent variables on the dependent variable. Hypothesis testing which states partially motivation influences lecturer performance is explained in table 1.

\section{Table 1}

Partial Test Results (T Test)

\begin{tabular}{crrrrr}
\hline Model & \multicolumn{2}{c}{ Unstandardized Coefficients } & $\begin{array}{c}\text { Standardized } \\
\text { Coefficients }\end{array}$ & \multirow{2}{*}{ T } & \multirow{2}{*}{ Sig } \\
\cline { 2 - 4 } & \multicolumn{1}{c}{ B } & Std. Error & Beta & & \\
\hline 1 (constant) & 65.190 & 10.054 & & 6.484 & .000 \\
Motivation & .808 & .143 & .646 & 5.649 & .000 \\
\hline
\end{tabular}

Source: Primary data processed, 2014

Based on the table above the value of $\mathrm{t}$ arithmetic for motivation is $5.649, \mathrm{t}$ table at significance 0.05: $2=0.025$ with degrees of freedom $\mathrm{df}=43-2-2=40$. The results obtained for $\mathrm{t}$ table are 2.021. Because the value of $\mathrm{t}$ count $>\mathrm{t}$ table, then $\mathrm{H} 0$ is rejected. So, it can be concluded partially that motivation affects the performance of the lecturer. Determination coefficients used to find out how much proportion or independent variables affect the dependent variable can be shown in table 2 .

Table 2

Regression Test Results (Coefficient of Determination)

\begin{tabular}{ccccc}
\hline Model & $\mathrm{R}$ & $\mathrm{R}$ Square & $\begin{array}{c}\text { Adjusted } \\
\text { R Square }\end{array}$ & $\begin{array}{c}\text { Std. Error of the } \\
\text { Estimate }\end{array}$ \\
\hline 1 & .596 & .355 & .333 & 12.40642 \\
\hline
\end{tabular}

Source: Primary data processed, 2014

Based on table 2, the results of testing the determination of the influence of lecturer performance variables are shown by the correlation between variables and supported by the coefficient of determination (adjusted R Square) of 0.333 which means 33.3\%. Lecturer performance variables as dependent variables can be predicted by motivational variables. Producing the remaining $66.7 \%$ is influenced by other variables outside the variable under study. The results of multiple linear regression analysis can be obtained from table 3 . 
$32 \mid$ Jurnal Ilmiah Ilmu Administrasi Publik: Jurnal Pemikiran dan Penelitian Administrasi Publik Volume 9 Number 1, January - June 2019. Page 29-36

Table 3

Linear Regression Test Results

\begin{tabular}{|c|c|c|c|c|c|}
\hline \multicolumn{6}{|c|}{ Coefficients } \\
\hline \multirow[t]{2}{*}{ Model } & Unstandardized & Coefficients & Standardized & $\mathbf{T}$ & Sig \\
\hline & B & Std. Error & Beta & & \\
\hline 1 (constant) & 65.190 & 10.054 & & 6.484 & .000 \\
\hline Motivation & .808 & .143 & 646 & 5.649 & .000 \\
\hline
\end{tabular}

Source: Primary data processed, 2014

Furthermore, based on linear regression analysis produces the regression equation as follows: $65,190+0,808 \mathrm{X}$. The regression coefficient for the Motivation variable $(\mathrm{X})$ is 0.808 . This shows that motivation influences the improvement of lecturers' performance at the Institute of Social and Political Sciences (IISIP), Yapis Biak.

\section{Discussion}

The results of the regression analysis show that motivation affects lecturer performance by 0.0808 , which means that motivation has a positive influence on lecturer performance by $80.8 \%$. This means that motivation is the driving force that creates the excitement of one's work, so that they will cooperate, work effectively and be integrated with all their efforts to achieve satisfaction. Motivation can be divided into two types, namely intrinsic motivation and extrinsic motivation. Based on the results of interviews conducted, there has been motivation given to lecturers, this is comparable to the partial test conducted where work motivation has a significant influence on the performance of the lecturer. Indikatoryang used to see the relationship between motivation and performance include 1) self-actualization, 2) awards and achievements, 3) expectations and stimuli and 4) promotion of positions. For indicators of selfactualization described with 5 items of questions, from the results of calculations with an error rate of $5 \%$, the result of $\mathrm{R}$ Square is 0.208 with a significance level of 0.0000 . this result shows motivation has contributed as much as $20.8 \%$. It can be concluded that when the lecturer feels heeded and his existence is acknowledged both individually and in groups it will increase his motivation so that he can improve the performance of the lecturer.

For the second indicator of Awards and Achievements, described with 5 items of questions with the calculation of the $5 \%$ error rate the result of $\mathrm{R}$ Square is 0.123 with a significance level of 0.0000 . this result shows motivation with contributions as 12.3 . Which shows that when the lecturer feels valued work results and the achievements he has made will continue to increase his motivation so that it will directly improve performance.

The third indicator is expectations and stimuli which are translated into 6 item questions with the results of calculating an error rate of $5 \%$ the result of $\mathrm{R}$ Square is 0.016 with a significance level of 0.0000 . these results indicate that expectations and stimuli can increase motivation with a contribution of $1.6 \%$. This shows that every lecturer has the hope to pay 
attention to their needs and need to be continuously stimulated to feel motivated to continue to improve their performance.

The Job Promotion Indicator is elaborated with 7 items of questions with an error rate of $5 \%$, the result of R Square is 0.240 with a significance level of 0.0000 . These results indicate that the promotion can increase motivation with a contribution of $24 \%$. This shows that the existence of career gaps and promotion offered by the institution can increase work motivation so that the performance shown is better.

Based on the results of the above research it can be concluded that the conditions at the Yapis Biak Institute of Social and Political Sciences and with the results of interviews revealed that the motivation given to lecturers still needed to be improved. Recognition of lecturers individually and in groups has been good, but in terms of awarding work performance and giving stimuli it is felt to be still uneven, because not all lecturers get appreciation and attention that is influenced by the existence of special interests between lecturers and leaders. In addition, many funding programs are lacking so that the motivation of lecturers decreases, for example lack of research funding support, thereby reducing the interest of lecturers to research.

\section{CONCLUSION}

Lecturer performance can be influenced by motivation. The results of the analysis and discussion obtained a linear regression equation, namely: $Y=65,190+0,808 X 1$ with the conclusion that Motivation affects the performance of lecturers of the Institute of Social and Political Sciences (IISIP) Yapis Biak, with the results of hypothesis testing Ho accepted and Ha rejected with a regression coefficient of 0.808 .

\section{REFERENCES}

Acar, O. A. (2018). Motivations and solution appropriateness in crowdsourcing challenges for innovation. Research Policy. https://doi.org/https://doi.org/10.1016/j.respol.2018.11.010

Andersson, T., Cäker, M., Tengblad, S., \& Wickelgren, M. (2019). Building traits for organizational resilience through balancing organizational structures. Scandinavian Journal of Management, 36 35-45. https://doi.org/https://doi.org/10.1016/j.scaman.2019.01.001

Bruhn, M., Schnebelen, S., \& Schäfer, D. (2014). Antecedents and consequences of the quality of e-customer-to-customer interactions in B2B brand communities. Industrial Marketing Management, $\quad 43(1), \quad 164-176$. https://doi.org/https://doi.org/10.1016/j.indmarman.2013.08.008

Chu, F., Fu, Y., \& Liu, S. (2019). Organization is also a "life form": Organizational-level personality, job satisfaction, and safety performance of high-speed rail operators. Accident Analysis \& Prevention, $125, \quad 217-223$. https://doi.org/https://doi.org/10.1016/j.aap.2019.01.027

Creswell, J. W., \& Creswell, J. D. (2017). Research design: Qualitative, quantitative, and mixed 
34| Jurnal Ilmiah Ilmu Administrasi Publik: Jurnal Pemikiran dan Penelitian Administrasi Publik Volume 9 Number 1, January - June 2019. Page 29-36

methods approaches. Sage publications.

Idzhar, A. (2016). Peranan Guru dalam Meningkatkan Motivasi Belajar Siswa. Jurnal Office, 2(2), 221-228.

Jamaluddin, J., Salam, R., Yunus, H., \& Akib, H. (2017). Pengaruh Budaya Organisasi terhadap Kinerja Pegawai pada Dinas Pendidikan Provinsi Sulawesi Selatan. Jurnal Ad'ministrare, $4(1), 25-34$.

Khunsoonthornkit, A., \& Panjakajornsak, V. (2018). Structural equation model to assess the impact of learning organization and commitment on the performance of research organizations. Kasetsart Journal of Social Sciences, 39(3), 457-462. https://doi.org/https://doi.org/10.1016/j.kjss.2018.07.003

McClelland, D. C. (1987). Human motivation. CUP Archive.

Ningsi, C. A., Alhabsji, T., \& Utami, H. N. (2016). Pengaruh Pelatihan Dan Promosi Terhadap Motivasi Dan Kinerja Karyawan (Studi Pada Karyawan Pt. pln (Persero) Area Kendari). Jurnal Ilmiah Ilmu Administrasi Publik, 5(2), 131-143.

Niswaty, R., Rusbiati, S., Jamaluddin, J., \& Salam, R. (2017). The Influence of Teacher's Reinforcement for Students Motivation. International Conference on Education, Science, Art and Technology, 148-152.

Ozer, L., \& Gultekin, B. (2015). Pre- and post-purchase stage in impulse buying: The role of mood and satisfaction. Journal of Retailing and Consumer Services, 22, 71-76. https://doi.org/https://doi.org/10.1016/j.jretconser.2014.10.004

Saggaf, M. S., Nasriyah, N., Salam, R., \& Wirawan, H. (2018). The Influence of Teacher's Pedagogic Competence on Learning Motivation of Student of Office Administration Expertise Package.

Saggaf, S., Salam, R., Kahar, F., \& Akib, H. (2014). Pelayanan Fungsi Administrasi Perkantoran Modern. Jurnal Ad'ministrare, 1(1), 20-27.

Salam, R., \& Rosdiana. (2016). Penerapan Fungsi Administrasi Perkantoran Modern Berbasis Daya Saing Organisasi dalam Menyongsong MEA 2015. SEMINAR NASIONAL "Revolusi Mental Dan Kemandirian Bangsa Melalui Pendidikan Ilmu-Ilmu Sosial Dalam Menghadapi MEA 2015” Himpunan Sarjana Pendidikan Ilmu-Ilmu Sosial Indonesia, 1(2016), 186-190. Fakultas Ilmu Sosial Universitas Negeri Makassar.

Salam, R., Rosdiana, Suarlin, \& Akib, H. (2014). The Impact Of Policy on Region Expansion to Office Administrative Services in Barombong Subdistrict of Gowa District. International Conference on Mathematics, Sciences, Technology, Education and Their Applications, 1(1), 505. State University of Makassar.

Sanjaya, A., \& Baharuddin, A. (2014). Pengaruh Gaya Kepemimpinan Transformasional Terhadap Motivasi Kerja Pegawai Pada Kantor Lembaga Penjamin Mutu Pendidikan Provinsi Sulawesi Selatan. Jurnal Ad'ministrare, 1(1), 72-83. 
Stollberger, J., Las Heras, M., Rofcanin, Y., \& Bosch, M. J. (2019). Serving followers and family? A trickle-down model of how servant leadership shapes employee work performance. Journal of Vocational Behavior, 112, 158-171. https://doi.org/https://doi.org/10.1016/j.jvb.2019.02.003

Syam, A., Akib, H., Yunus, M., \& Hasbiah, S. (2018). Determinants of entrepreneurship motivation for students at educational institution and education personnel in Indonesia. Journal of Entrepreneurship Education.

Wahab, N. A., Hassan, L. F. A., Shahid, S. A. M., \& Maon, S. N. (2016). The Relationship Between Marketing Mix And Customer Loyalty In Hijab Industry: The Mediating Effect Of Customer Satisfaction. Procedia Economics and Finance, 37, 366-371. https://doi.org/https://doi.org/10.1016/S2212-5671(16)30138-1 
36 Jurnal Ilmiah Ilmu Administrasi Publik: Jurnal Pemikiran dan Penelitian Administrasi Publik Volume 9 Number 1, January - June 2019. Page 29-36 